\title{
THE JADHAV CASE, INDIA V. PAKISTAN (ONGOING CASE AT THE INTERNATIONAL COURT OF JUSTICE, 2017)
}

Keywords

ICJ - Jadhev - consular rights - India - Pakistan

\section{INTRODUCTION}

The case regarding Mr Kulbhushan Sudhir Jadhav (hereinafter Jadhav) which once again raises the tension between India and Pakistan, was submitted by India, the Applicant in the current dispute under Article 36(1) of the Statute of the International Court of Justice (hereinafter the Statute), on 8 May $2017^{1}$, together with a Request for the Indication of the Provisional Measures of Protection ${ }^{2}$. This article briefly describes

* Prof. dr hab. Tadeusz Wasilewski, Department of Public International Law, Faculty of Law and Administration, Nicolaus Copernicus University; tadwas@umk.pl.

** Dr Maciej Żenkiewicz, Research professor, Universidad de Externado de Colombia; maczen@umk.pl.

${ }^{1}$ Case Concerning the Vienna Convention on Consular Relations (India v. Pakistan), Application instituting proceeding, filed in the Registry of the Court on 8 May 2017, ICJ, available at http:/ / www.icj-cij.org/files/case-related/168/19422.pdf [last accessed 20.10.2017] [hereinafter Application, 8 May 2017].

2 Case Concerning the Vienna Convention on Consular Relations (India v. Pakistan), Request for the Indication of the Provisional Measures of Protection, 8 May 2017, ICJ, 
and comments on the ongoing procedure: the recently issued Order of the Court ${ }^{3}$ and the possible outcome of the clash of the long-standing rivals: India and Pakistan.

\section{BRIEF FACTS OF THE CASE}

Mr Jadhav, an Indian national and retired Indian naval officer was allegedly arrested on 3 March 2016. On 25 March 2016 India was informed of that fact, and since then India repeatedly sought consular access to the said individual (more than thirteen times). The first official response from Pakistan was received on 23 January 2017, when India received a request from Pakistan for assistance in investigation of what was described as "FIR No. 6 of 2016". Next, on 21 March 2017, Pakistan in a note verbale to India, stated that "the case for consular access to the Indian national... shall be considered in the light of the Indian side's response to Pakistan's request for assistance in investigation process and early dispensation of justice" ${ }^{\prime \prime}$. Such a limitation on the right of consular access by a State to its national, as argued by India, is against Pakistan's obligation under the Vienna Convention on Consular Relations 1963 (hereinafter VCCR). By unofficial channels of communications (from the press) India learned on 10 April 2017 that Mr. Jadhav was sentenced to death by the military tribunal for his alleged involvement in espionage and terrorist activities in Pakistan, and Pakistan repeated that day the proposal of 21 March 2017, that consular access to Mr. Jadhav be considered under the condition of the Indian assistance in investigation process.

available at: http://www.icj-cij.org/files/case-related/168/19424.pdf [last accessed 20.10.2017][hereinafter, Request, 8 May 2017].

${ }^{3}$ Case Concerning the Vienna Convention on Consular Relations (India v. Pakistan), Order of the ICJ, 18 May 2017, available at http://www.icj-cij.org/files/caserelated/168/168-20170518-ORD-01-00-EN.pdf [last accessed 20.10.2017][hereinafter Order, 18 May 2017).

4 See Application, 8 May 2017, at p. 6-7. 


\section{Proceedings before the IC]}

Apart from assisting the mother of Mr. Jadhav to file an appeal from that sentence within the Pakistani legal system, India decided to start proceedings against Pakistan and in the light of "the extreme gravity and immediacy of the threat that authorities in Pakistan will execute an Indian citizen in violation of obligations Pakistan owes to India" ${ }^{5}$ to request the Court for provisional measures, especially asking the Court to indicate that ",the Government of the Islamic Republic of Pakistan take all measures necessary to ensure that Mr. Kulbhushan Sudhir Jadhav is not executed" 6 .

To summarise, India accused Pakistan of: violation of the rights of Mr Jadhav to be informed of his rights to seek assistance from India (article 36(1)(b) of VCCR); violation of article 14 of the 1966 International Covenant on Civil and Political Rights, because Pakistan fail to accord Mr Jadhav 'elementary rights of the accused'; and violation of article 36(1)(a) and article 36(1)(c) of VCCR by denying India of the exercise of its right to seek consular access to Mr Jadhav, to arrange for his legal representation and to correspond and converse with him ${ }^{7}$.

Regarding jurisdictional issues India argues that the Court has jurisdiction under Article I of the Optional Protocol to the VCCR concerning the Compulsory Settlement of Disputes (hereinafter Optional Protocol) which grants compulsory jurisdiction to the ICJ in matters of interpretation of the $\mathrm{VCCR}^{8}$, and not on the basis of declarations made accepting the compulsory jurisdiction of the Court in term of Article 36(2) of the Statute 9 . By using Article 36(1), instead of Article 36(2), of the ICJ Statute, India has limited the final scope of its application to remedies for lack of access to Mr. Jadhav. On the other hand, by using article 36(1) of the Statute India escapes from the dispute and possible objections to

${ }^{5}$ See Request, 8 May 2017, para 23.

${ }^{6}$ Ibid. para 22.

7 See Application, 8 May 2017, at p. 23 at seq. See also Order, 18 May 2017, Declaration of Judge Dalveer Bhandari.

${ }^{8}$ India and Pakistan ratified the Optional Protocol in 1977 and 1976 respectively.

9 To which both States made various reservations. 
compulsory jurisdiction in light of the Pakistan and India reservations to the ICJ jurisdiction.

\section{Provisional measures}

It is worth mentioning, that under article 41 of the Statute: "the Court shall have the power to indicate, if it considers that circumstances so require, any provisional measures which ought to be taken to preserve the respective rights of either party." In the current case, the Court could indicate provisional measures if 'the dispute' within the meaning of Article 1 of the Optional Protocol exists, and if the provisions invoked by India appear, prima facie, to afford basis on which jurisdiction of the Court could be founded.

The provisional measures hearings in the Jadhav case were conducted on 15 May $2017^{10}$. India has presented the arguments for the jurisdiction of the Court (Article I of the Optional Protocol) and also has acknowledged that both States had entered into a Bilateral Agreement on Consular Access in 2008 (hereinafter Bilateral Agreement 2008) which, in the opinion of India, supplemented the VCCR, not replaced it. Pakistan argued that by its declaration under article 36(2) of the Statute and taking into account the Bilateral Agreement $2008^{11}$, VCCR is inapplicable in the current dispute. What is more, in the opinion of the Pakistan, VCCR does not apply to persons accused of espionage and terrorist activities. Therefore, in the light of those arguments the ICJ has no jurisdiction to resolve this case.

The Court in its Order of 18 May, 2017, after hearing held on 15 May 2017 decided that: it has prima facie jurisdiction under the Article 1 of the Optional Protocol of the VCCR to entertain the dispute between the Parties"12.

${ }^{10}$ Before the hearings, acting under the Rule of the Court 74 (7), on 8 May 2017 the President of the ICJ requested Pakistan to "act in such a way as will enable any order the court may make on this request to have its appropriate effects".

${ }_{11}$ Article VI states: "in case of arrest, detention or sentence made on political or security grounds, each side may examine the case on its merits".

12 Order, 18 May 2017, para 34. 
To support that conclusion, the Court stated:

a) "the dispute existed between the Parties as to the question of consular assistance under the Vienna Convention with regard to the arrest, detention, trial and sentencing of Mr. Jadhav"13;

b) that need not to examine Pakistan reservations to the Court's jurisdiction made while accepting the compulsory jurisdiction under art. 36 (2), because in that case the prima facie jurisdiction is found on the treaties and conventions in force pursuant to Article 36 (1) of its Statute and therefore it becomes irrelevant to consider the objections to the other possible bases of jurisdiction ${ }^{14}$. Also the ICJ stated that at this stage of the proceeding, it is not required to address the issue if the Bilateral Agreement 2008 limits the rights contained in the article 36 of the $\mathrm{VCCR}^{15}$. The existence of the Bilateral Agreement 2008 between the parties does not change its conclusions on jurisdiction;

c) that it has jurisdiction rationae materiae on the basis of Article 1 of the Optional Protocol ${ }^{16}$;

d) that the rights alleged by India are plausible;

e) that exists a link between the rights claimed by India and the provisional measures being sought.

Also to justify the provisional measures, the Court should prove, that without such a measures an ,irreparable prejudice could be caused to rights which are the subject of judicial proceedings" ${ }^{17}$. In the current dispute, the Court stressed that Pakistan did not give any assurance that it would not execute the death sentence before the final decision of the Court, and therefore "the conditions required by its Statute for

13 Ibid., para 29.

14 Ibid., para 26.

15 Ibid., para 33.

16 Through the ostensible violation of India's rights to communicate and have access to Mr Jadhav. See Order, 18 May 2017, para 30.

17 See the Application of the International Convention for the Suppression of the Financing of Terrorism and the International Convention on the Elimination of All Forms of Racial Discrimination (Ukraine v. Russian Federation), Provisional Measures, Order of 19 April 2017, ICJ, para 88. Available at: http://www.icj-cij.org/files/caserelated/166/19394.pdf [last accessed 20.10.2017]. 
it to indicate provisional measures are met"18. As a result the Court ordered ,that Pakistan shall take all measures at its disposal to ensure that Mr. Jadhav is not executed pending the final decision in these proceedings and shall inform the Court of all measures taken in implementation of the present Order" ${ }^{* 19}$.

\section{BINDING NATURE OF THE PROVISIONAL MEASURES}

In the current dispute it seems undisputed that the indication of provisional measures by the Court is binding on Pakistan ${ }^{20}$. Following the Avena case ${ }^{21}$, the Court used also this time the word "shall" to describe the obligation of state. This differs from the words employed in the LaGrand and the Breard cases, when the Court, by using the word 'should' to characterize the obligation of State, leaves some doubts regarding its binding nature ${ }^{22}$. The doubts in the Breard case were followed by the US Secretary of State, who was of an opinion that provisional measures were of the non-binding nature. Such interpretation was later presented by the US Solicitor General in the LaGrand case before the US Supreme Court²3.

18 Order, 18 May 2017, para 57.

19 Ibid.

${ }^{20}$ See P. S. Rao, The Jadhav case (2017): India and Pakistan before the International Court of Justice, "Indian Journal of International Law" published online 9 August 2017, p. 15: https:// doi.org/10.1007/s40901-017-0063-6 [last accessed 20.10.2017].

${ }^{21}$ Case Concerning Avena and Other Mexican Nationals (Mexico v. United States of America), Request for the Indication of Provisional Measures, Order of 5 February 2003, ICJ, para 59, available at: http:/ / www.icj-cij.org/files/ case-related/128/128-20030205-ORD02-00-EN.pdf [last accessed 20.10.2017] (hereinafter Avena case, Order February 5, 2003).

22 Case LaGrand (Germany v. United States of America), Order of 3 March 1999, ICJ, para 29, available at: http:/ / www.icj-cij.org/files/ case-related/104/104-19990303-ORD01-00-EN.pdf [last accessed 20.10.2017], (hereinafter LaGrand case, Order, 3 March 1999); Vienna Convention on Consular Relations (Paraguay v. United States of America), Order of 9 April 1998, ICJ, para 41, available at: http:/ / www.icj-cij.org/ files/case-related/99/09919980409-ORD-02-00-EN.pdf [last accessed 20.10.2017] (hereinafter Breard case).

${ }^{23}$ See P. S. Rao, supra note 20, p. 15. See also LaGrand (Germany v. United States of America), Judgment of 27 June 2001, ICJ, para 33, available at: http://www.icj-cij. org/files/case-related/104/104-20010627-JUD-01-00-EN.pdf [last accessed 20.10.2017] (hereinafter LaGrand case, Judgment 27 June 2001). 
Such an interpretation of the non-binding nature of the provisional measures in the Breard case was criticized by scholars ${ }^{24}$, and in the LaGrand case was expressly denied by the Court itself in its decision on the merits. The Court stressed that: "by failing to take all measures at its disposal to ensure that Walter LaGrand was not executed pending the final decision of the International Court of Justice in the case, the United States of America breached the obligation incumbent upon it under the Order indicating provisional measures... “25.

Therefore it should be positively assessed, that the Court follow the wording of the Avena case in the current dispute and leaves no doubt regarding the binding nature of the provisional measures.

\section{WHAT AFTER THE ORDER?}

Following the Court Order from 13 June 2017, India had time until 13 September and Pakistan until 13 December to complete the written pleadings. Obviously, first the Court will decide the question of its jurisdiction in the current disputes which seems to be the main judicial battle between India and Pakistan. It has to be remembered, that the decision of the Court on 18 May 2017 on prima facie jurisdiction does not imply final jurisdiction in the matter as was observed by the Court in the LaGrand case. The Court in that case specifically observed that: "whereas, on a request for the indication of provisional measures the

${ }^{24}$ See L. Henkin, Provisional Measures, U.S. Treaty Obligations, and the States, "American Journal of International Law“1998, vol. 92, p. 683; see also C. Drinan, Article 36 of the Vienna Convention on Consular Relations: Private Enforcement in American Courts after LaGrand, "Stanford Law Review" 2002, vol. 53, p. 1303. See also regarding that case: J. Frowein, Provisional Measures by ICJ, LaGrand Case, "Heidelberg Journal of International Law" 2002, vol. 62, p. 54; R. Jennings, The LaGrand Case "Law and Practice of the International Court and Tribunals“ 2002, vol. 1, p. 13.

${ }^{25}$ LaGrand case, Judgment 27 June 2001, para 128 (5). The previous cases against United States of America (Breard case, LaGrand case and Avena case) shows similarities to the current disputes with one significant difference. In the case of the United States of America, there was a crucial problem of the implementation of ICJ provisional measures, as not self-executing in the US system. In the case in hand, there should be no such hurdles. See A.M. Weisburd, International Courts and American Courts, "Michigan Journal of International Law“2 2000, vol. 21, p. 877. 
court need not, before deciding whether or not to indicate them, finally satisfy itself that it has jurisdiction on the merits of the case, but whereas it may not indicate them unless the provisions invoked by the Applicant appear, prima facie, to afford a basis on which the jurisdiction of the court might be founded." 26

Pakistan's first line of defence will be to question the Court's jurisdiction in the current dispute. It can be assumed that Pakistan will raise following arguments:

a) that the ICJ should allow for the application of the Bilateral Agreement 2008, even if that treaty has not been registered with the Secretariat of the UN before 17 May 201727. So in the light of that late registration the ICJ can have a chance to decide on the effect of the non-registration and delayed registration of a treaty;

b) that the Bilateral Agreement 2008 limit the application of the $\mathrm{VCCR}^{28}$, and under article 6 of Bilateral Agreement 2008 each state is allowed to examine an arrest made on political or security grounds on its own merits and therefore potentially deny consular access.

\section{MERITS}

If the arguments of India prevail the Court will move to the merit phase. During that phase the Pakistani representative will find themselves in a very difficult position. In the light of the previous ICJ's judgments, Pakistan will face the difficult task of proving that its actions have not violated the rights enshrined under Article 36 (1) (a), (b) or (c) of the VCCR. Even if the Court has stated that the requirement of "without delay' does not mean 'immediately' ${ }^{29}$, still as the Court clearly indicate

${ }^{26}$ LaGrand case, Order 3 March 1999, para 13.

27 The Agreement has been registered after the dispute arisen, on 17 May 2017, Registration ID 54471.

${ }^{28}$ According to the VCCR article 73 (2): "Nothing in the present Convention shall preclude States from concluding international agreements confirming or supplementing or extending or amplifying the provisions thereof".

${ }^{29}$ Case Concerning Avena and Other Mexican Nationals (Mexico v. United States of America), Judgment of the ICJ of 31 March 2004, ICJ, para 88, available at: http:// 
"there is nonetheless a duty upon the arresting authorities to give that information to an arrested person as soon as it is realized that the person is a foreign national, or once there are grounds to think that the person is probably a foreign national" ${ }^{\prime \prime}$. What is more, the Court has also stressed on various occasions that "it is immaterial whether [the State] would have offered consular assistance, or whether a different verdict would have been rendered. It is sufficient that the Convention conferred these rights, which might have been acted upon" ${ }^{\prime 31}$. Therefore, taking into account the facts of the case, it seem very improbable that the Court will find that neither of the obligations enshrined in article 36 (1) (a), (b) or (c) has been violated by the conduct of Pakistan.

In the possible scenario that the Court will find a violation of any or all of the rights under 36 (1) (a), (b) or (c), as the similarities to the previous cases cannot be overlooked, the outcome of the ICJ proceeding may be review and reconsideration of the Jadhav case in the Pakistan courts $^{32}$. As in the LaGrand case the ICJ stated, that US must "allow the review and reconsideration of the conviction and sentence by taking account of the violation of the rights set forth in [the VCCR]"33. The primordial question is, what does it mean to review and reconsider the case? In case of the ICJ decision Pakistan has violated the rights of India and, as in the previous case would demand 'review and reconsideration'. Such a decision should be understood as a request to allow for a judicial review of the conviction of Mr Jadhav. The cases regarding the US were different from the case in hand, because the question of possible remedy and "review and reconsideration" of the conviction clash with the complicated US clemency system. The decision to start proceedings for clemency after a state conviction is not in the hands of the President of the United States of America, but rather in those of the Governor or

www.icj-cij.org/files/case-related/128/128-20040331-JUD-01-00-EN.pdf [last accessed 20.10.2017], (hereinafter Avena case, Judgment 31 March 2004).

30 Ibid.

${ }^{31}$ Avena case, Judgment 31 March 2004, para 102. See also para 103 discussing the rights under article $361 \mathrm{c}$.

32 See ibid. para 121.

${ }^{33}$ LaGrand case, Judgment 27 June 2001, para 128 (7). 
Parole Board. ${ }^{34}$ But may the clemency proceedings satisfy the review and reconsideration requirement? In that respect, what is important is to allow for a substantive hearing on a violation of the VCCR rights of the defendant. So, for example Pakistan would not fulfil such a requirement by simply stating that clemency was taken into account and denied. As scholars stressed after the LaGrand case "a hearing on the merits of the VCCR issue is necessary to give full effect to the VCCR notification rights" 35 .

\section{LONG STANDING REPERCUSSIONS OF THE INDIA APPLICATION}

Apart from the outcome for the Jadhav case, the current proceedings can have far reaching repercusions for India-Pakistan relations. So far, the position of India was that all issues with Pakistan would be resolved rather bilaterally. As India's Congress spokesperson - Ajoy Kumar explained: "the best resolution (of issues) is bilateral at all times, no matter how recalcitrant Pakistan is" ${ }^{\prime 36}$. Such an attitude can be explained by the threat that the conflicts, such as Kashmir issue or the KishanGanga power project, which were successfully kept at bay by India from the international courts, may finally be brought by Pakistan for an international adjudication. Therefore, some of the commentators from India $^{37}$ see it as a possible definitive break from the attitude of India in the past to resolve all the issues with Pakistan on the bilateral plane

${ }^{34}$ See L. E. Carter, Compliance with ICJ Provisional Measures and the Meaning of Review and Reconsideration under the Vienna Convention on Consular Relations: Avena and Other Mexican Nationals (Mex. v. U.S.), "Michigan Journal of International Law” 2003-2004, vol. 25, p. 129.

${ }^{35}$ Ibid., p. 131.

${ }^{36}$ See Kulbhushan Jadhav case: Congress criticises, Left welcomes Hague move, „The Times of India" 11 May 2017. Available at: https:/ / timesofindia.indiatimes.com/india/kulbhushanjadhav-case-congress-criticises-left-welcomes-hague-move/articleshow/58618278.cms [last accessed 25.10.2017].

${ }^{37}$ See D. Sharma, India v. Pakistan - Round Four, "JURIST - Professional Commentary", 10 July 2017, available at http://jurist.org/professional/2017/07/dhruv-sharma-indiapakistan.php [last accessed 25.10.2017]. 
or even as an opening Pandora's box ${ }^{38}$. However such an attitude may be assessed from the viewpoint of India, positively or negatively, for international law it is very good news. It means that finally some very tense and problematic issues between those two nations may be resolved on the international plane in a pacific manner.

\section{CONCLUSIONS}

Many times the disputes before the ICJ touch upon important issues for a State and for state policy. The decisions affect territorial disputes, the interpretation of treaties, or global policy. This case is no different. It touches upon the very important issues of consular rights. But also, as was discussed in that article, the case in hand may have that important longstanding result of finally opening the door for international adjudication to resolve all the disputes between the rivals in the region, India and Pakistan. What is more, apart from that, the proceedings before the Court have a very particular and measurable issue at stake - the life of Mr. Jadhav. It is interesting to see how international law and the ICJ in particular can affect not only very important global issues and the rights of States, but also the life (and this time in a very ordinary meaning) of an individual. The next time the sceptics say that international law does not work, the true example of Mr. Jadhev can be raised, because in his situation international law so far has postponed his execution, and will maybe lead to the reopening of his case and a retrial, of the proceedings, but this time, with proper consular assistance.

38 See A. Trivedi, ICJ Jurisdiction on Bilateral Issues Possibilities Regarding Jammu and Kashmir Dispute, "JURIST - Student Commentary", 19 July 2017, available at http:/ / jurist.org/dateline/2017/02/abhishek-trivedi-icj-pandora.php [last accessed 25.10.2017]. 
